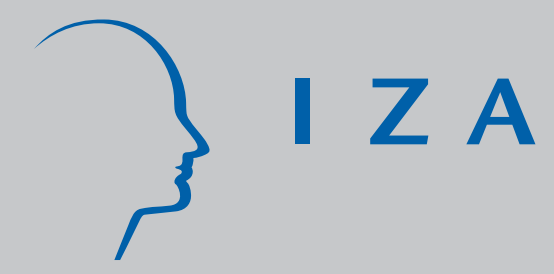

IZA DP No. 3861

The East German Wage Structure after Transition

Robert Orlowski

Regina T. Riphahn

November 2008 


\title{
The East German Wage Structure after Transition
}

\author{
Robert Orlowski \\ University of Erlangen-Nuremberg \\ Regina T. Riphahn \\ University of Erlangen-Nuremberg \\ and IZA
}
Discussion Paper No. 3861
November 2008

\author{
IZA \\ P.O. Box 7240 \\ 53072 Bonn \\ Germany \\ Phone: +49-228-3894-0 \\ Fax: +49-228-3894-180 \\ E-mail: iza@iza.org
}

\begin{abstract}
Any opinions expressed here are those of the author(s) and not those of IZA. Research published in this series may include views on policy, but the institute itself takes no institutional policy positions.

The Institute for the Study of Labor (IZA) in Bonn is a local and virtual international research center and a place of communication between science, politics and business. IZA is an independent nonprofit organization supported by Deutsche Post World Net. The center is associated with the University of Bonn and offers a stimulating research environment through its international network, workshops and conferences, data service, project support, research visits and doctoral program. IZA engages in (i) original and internationally competitive research in all fields of labor economics, (ii) development of policy concepts, and (iii) dissemination of research results and concepts to the interested public.
\end{abstract}

IZA Discussion Papers often represent preliminary work and are circulated to encourage discussion. Citation of such a paper should account for its provisional character. A revised version may be available directly from the author. 
IZA Discussion Paper No. 3861

November 2008

\section{ABSTRACT \\ The East German Wage Structure after Transition*}

We extend the literature on transition economies' wage structures by investigating the returns to tenure and experience. This study applies recent panel data and estimation approaches that control for hitherto neglected biases. We compare the life cycle structure in East and West German wages for fulltime employed men in the private sector. The patterns in the returns to seniority are similar for the two regional labor markets. The returns to experience lag behind in the East German labor market, even almost 20 years after unification. The results are robust when only individuals are considered who started their labor market career in the market economy and they hold across skill groups.

JEL Classification: J31, J24

Keywords: $\quad$ wage structure, life cycle earnings, returns to tenure, returns to experience

Corresponding author:

Regina T. Riphahn

Economics Department

Univ. of Erlangen-Nuremberg

Lange Gasse 20

D - 90403 Nuremberg

Germany

E-mail: Regina.Riphahn@wiso.uni-erlangen.de

\footnotetext{
* We thank Jennifer Hunt, Katja Sonderhof as well as participants of the economics seminar at the University of Regensburg, the DFG-SPP summer school 2008, and the DFG-SPP Oct. 2008 workshop at RWI Essen for helpful comments.
} 


\section{Introduction}

Much interest focuses on the adjustment of transition economies' wage structures on the path to market oriented economies. Numerous contributions investigate the development of returns to human capital in transition economies and test whether the abolition of wage grids and socialist wage compression has lead to more dispersed wages and to increases in the returns to human capital (see e.g. Andrén et al. 2005, Gorodnichenko and Sabirianova Peter 2005, Flanagan 1998, Boeri and Flinn 1999, or Liu 2006). In their meta-analysis of this literature Fleisher et al. (2005) present a record of rising returns to education throughout.

However, the focus on the rising returns to education might be misleading if at the same time wages remained irresponsive to other dimensions of human capital. Interestingly, only a handful of studies in this literature investigate the development of returns to tenure and experience. Among them are Jones and Ilayperuma Simon (2005) who take advantage of Bulgarian employer-employee data. They find that returns to education about doubled after transition while returns to experience stayed constant at low levels. Münich et al. (2005) look at the development of the Czech wage structure and confirm a dramatic increase in the returns to education, yet no shift in the returns to experience at the end of the communist regime. Noorkoiv et al. (1997) study the case of Estonia where returns to schooling increased sharply between 1989 and 1995 whereas the age-earnings profile flattened.

A possible explanation for the different developments in the returns to human capital inherent in schooling and in labor market experience might be related to the specific adjustments coinciding with economic transition. If schooling were a valid signal for innate individual productivity it could be remunerated immediately. Socialist labor market experience, however, may have been only of limited value such that it took time for labor market experience in the market economy to accumulate value. This might explain why the adjustment in returns to experience lags behind the adjustment in returns to education. 
In this study we compare the East and West German wage structures almost two decades after unification in order to investigate whether systematic differences in the returns to experience and tenure in the two regional labor markets have disappeared over time. In 1990 East and West Germany became one country, sharing since not only history and language but also labor market institutions. Much has been written about the transition process in East Germany and optimistic studies from the early 1990s have been replaced by more somber assessments. ${ }^{1}$

This study contributes to the literature in various ways: first, in contrast to most analyses which study labor market adjustments of former socialist countries on their way market oriented economies, in the case of Germany we can take advantage of a benchmark economy. East Germany is adjusting to an institutional setting which at the same time and identically determines West German labor market outcomes. This allows us to identify the consequences of a socialist heritage in a comparative perspective, which is not available for other countries. Second, we improve on the least squares approach which predominates in studies of wage structures in transition economies and account for the endogeneity of tenure and experience. We apply the more advanced estimators of Altonji and Shakotko (1987) and Topel (1991). Estimates based on these procedures at times differ vastly from the biased least squares results. Third, we apply recent and representative panel data evidence on life-cycle wage structures. Finally, since Görzig et al. (2008) point to shifts in the sectoral and occupational employment structure as the main determinant of differences in wage levels in East and West Germany, we carefully control for such composition effects.

Our results are of immediate policy relevance: German active labor market policies spent large amounts to create public employment opportunities for the East German labor force (for a survey see Fertig et al. 2006). If there are no or only low returns to experience

\footnotetext{
${ }^{1}$ For recent contributions see Snower and Merkl (2006) or Uhlig (2006, 2008). For accounts of German unification and its labor market aspects see e.g. Steiner and Bellman (1995), Burda and Schmidt (1997), Franz and Steiner (2000), Burda and Hunt (2001), Hunt (2001), Spitz-Oener (2007), or Burda (2006, 2008).
} 
then the payoff of expensive public employment is much lower than expected. In addition, prior analyses of transition economies' labor market adjustments may have been too optimistic when they built their conclusions on the increasing returns to schooling only. Taking returns to experience and tenure into account the transition processes in labor markets may be much slower than assumed so far.

In the East German labor market immediately prior to unification returns to experience and tenure were half those earned in West Germany (Bird et al. 1994) and life cycle wage heterogeneity was much below West German levels (Krueger and Pischke 1995). Burda and Schmidt (1997, p.195) studied the early adjustment process of wages in East Germany through 1993 and concluded that "returns to age were depressed under socialism and continue to be so several years after market relations were introduced." Jurajda and Harmgart (2007) find that in 1995 the experience profile was considerably flatter in East than in the West Germany. Based on data through 1997, Franz and Steiner (2000, p.260) find that in the East German private sector "wages do not increase with general labor market experience (...)". Gathmann (2005) added a new perspective to the debate by comparing the ratio of East to West German wages separately by age group and over time. She found that the relative wage difference was largest for older, i.e. more experienced workers throughout the first ten years after unification. This suggests that even ten years after unification the flat wage experience profile of the socialist economy had not disappeared.

We apply data from the 2002-2006 surveys of the German Socioeconomic Panel (SOEP Group, 2001) on East and West German wage structures. We provide evidence on returns to tenure and experience and investigate whether socialist labor market institutions continue to characterize East German wages. Numerous commentators interpreted the previously observed lack of returns to experience in East Germany as a consequence of the obsolescence of general human capital following reunification. We test whether these findings are due to a cohort effect that disappears when only those cohorts are considered 
who entered the labor market after 1990. As wage structures are generally heterogeneous across skill groups we additionally study East and West German life cycle wages by skill group.

Our key results are that the returns to tenure are small but similar in East and West Germany, while the experience profiles still differ substantially even after controlling for potential composition effects. We discuss possible interpretations of this evidence, which suggests that it takes at least one generation to leave the socialist heritage behind.

\section{Estimation Approach}

The key challenge in identifying the causal returns to tenure and experience in a wage model is to account for the potential endogeneity of the measures of human capital. This problem has been neglected in the transition economics literature on the development of wage structures so far. Let for person $\mathrm{i}$ in employment $\mathrm{j}$ at period $\mathrm{t}$

$$
\mathrm{W}_{\mathrm{ijt}}=\mathrm{b}_{1} \mathrm{~T}_{\mathrm{ijt}}+\mathrm{b}_{2} \mathrm{E}_{\mathrm{ijt}}+\mathrm{e}_{\mathrm{ijt}} \text {, }
$$

where $\mathrm{W}$ represents the log real hourly wage, $\mathrm{T}$ and $\mathrm{E}$ represent (polynomials of) tenure and experience. Other control variables may enter (1) but are ignored here for ease of exposition. $b_{k}$ are coefficients to be estimated. $e_{i j t}$ is the error term, which is assumed to combine fixed individual effects $\left(e_{i}\right)$, fixed job match effects $\left(e_{i j}\right)$, and a random term $\eta_{i j t}$

$$
e_{i j t}=e_{i}+e_{i j}+\eta_{i j t}
$$

There are several reasons why $\mathrm{T}$ or $\mathrm{E}$ may be correlated with components of the error term, which unless accounted for causes biased and inconsistent least squares estimates of the return parameters $b_{k}$ : tenure may be correlated with $e_{i}$ if person-specific characteristics affect the stability of employment relationships as well as wages. Also, job match-specific unobservables $\mathrm{e}_{\mathrm{ij}}$ are likely to affect the probability of quits and thereby of observed tenure. In addition, we observe only those selected new employment relationships which improve 
individual outcomes. An overall positive correlation between tenure and the unobservables would lead to an overestimation of the least squares coefficient.

Experience may be correlated with $\mathrm{e}_{\mathrm{ijt}}$ as matching and job search processes increase the probabilities of a good match the longer an individual is active on the labor market. This may generate a positive correlation between experience and the match specific error component $\mathrm{e}_{\mathrm{ij}}$. If individuals with specific unobserved characteristics such as motivation spend more time in the labor market, this correlation between experience and $e_{i}$ may yield an overestimate of the returns to experience.

Two classic approaches to deal with these potential endogeneities are suggested by Altonji and Shakotko (AS, 1987) and Topel (1991). AS address the endogeneity of tenure using an instrumental variables approach. They instrument all tenure indicators based on the difference between the period-specific and the average value $\bar{T}_{i j}$ for a given job match $j$ of person $\mathrm{i}^{2}$

$$
\tilde{\mathrm{T}}_{\mathrm{ijt}}=\mathrm{T}_{\mathrm{ijt}}-\overline{\mathrm{T}}_{\mathrm{ij}}
$$

This instrument is correlated with $\mathrm{T}$ and uncorrelated with person- and match-specific unobservables thus solving the endogeneity problem. ${ }^{3}$ The endogeneity of experience both with respect to $e_{i}$ and $e_{i j}$ is not accounted for in this approach, which is why $b_{2}$ may be biased upward. Since tenure and experience are generally positively correlated overestimated returns to experience generate underestimated returns to tenure.

As a second estimator, we apply Topel's (1991) two-step procedure: step one estimates average within-job annual wage growth for individuals who did not change jobs.

\footnotetext{
${ }^{2}$ There may be more than one tenure indicator due to higher order polynomial and interaction terms.

${ }^{3}$ Dustmann and Pereira (2008) discuss an alternative approach introduced by Finnie (1999), which corrects only for the correlation between tenure and person-specific error terms. Their estimates for West German data show that the returns to tenure based on this approach (which uses the difference between $\mathrm{T}_{\mathrm{ijt}}$ and the average of $\mathrm{T}_{\mathrm{i}}$ ) are between those generated by OLS and AS.
} 
This allows identification of the sum of the returns to seniority $\left(b_{1}\right)$ and to experience $\left(b_{2}\right)$ in the constant term, because $\Delta \mathrm{T}=\Delta \mathrm{E}=1^{4}$ and in the simple linear representation ${ }^{5}$

$$
W_{i j t}-W_{i j t-1}=\left(b_{1}+b_{2}\right)+e_{i j t}-e_{i j t-1}
$$

Step two then investigates the earnings of workers who started new jobs. As they have not yet accumulated seniority a cross-sectional estimation of the returns to experience of individuals with zero tenure identifies their returns to general labor market experience:

$$
\mathrm{W}_{\mathrm{ijt}}=\mathrm{b}_{2} \mathrm{E}_{\mathrm{ij} 0}+\mathrm{e}_{\mathrm{ijt}} \text {, }
$$

Here $E_{\mathrm{ij} 0}$ reflects the initial experience of workers starting a new job. The returns to seniority are then approximated as the difference in the returns found in steps one and two of the analysis.

To obtain these estimates the literature proceeds by rewriting total experience as the sum of initial experience on the new job and current tenure,

$$
E_{\mathrm{ijt}}=\mathrm{E}_{\mathrm{ij0}}+\mathrm{T}_{\mathrm{ijt}}
$$

which then generates the following wage equation

$$
W_{i j t}=\left(b_{1}+b_{2}\right) T_{i j t}+b_{2} E_{i j 0}+e_{i j t} .
$$

The second step regression thus uses

$$
W_{i j t}-T_{i j t} b^{*}=b_{2} E_{i j 0}+e_{i j t},
$$

where $b^{*}$ is the estimated value of $\left(b_{1}+b_{2}\right)$ from step 1 (see equation 4 ). We follow this approach and additionally consider changes in a large set of control variables when estimating $b^{*}$.

Unbiased estimators result only if the groups of individuals who did not change jobs and those who started a new job are randomly selected and if their characteristics are not correlated with the unobservables. Since this is unlikely to be the case, Topel (1991)

\footnotetext{
${ }^{4}$ With strictly annual data the differences in tenure and experience values from year to year are exactly equal to one. In our data interview dates vary. However we are able to take advantage of precise information and can minimize measurement error by considering the actually observed change in tenure and experience when estimating $\left(b_{1}+b_{2}\right)$.

${ }^{5}$ The procedure generalizes to a non-linear specification. We applied second and third order polynomials in tenure and experience.
} 
interprets his estimate of $b_{2}$ as an upper bound such that the resulting estimate of $b_{1}$ is a lower bound of the returns to seniority. While both, the AS and the Topel estimators rely on restrictive assumptions, both improve on the least squares approach to estimate the returns to tenure and experience and are frequently applied in this literature (see e.g. Parent 2000, Luchsinger et al. 2003, or Dustmann and Pereira 2008).

\section{Data}

We use the 2002-2006 waves of the German Socio-Economic Panel (SOEP Group 2001), a representative panel on German households. We consider full-time employed males, aged 25-60, who are not self-employed, not in vocational training, not in marginal jobs and who work in the private sector. ${ }^{6}$ Our West and East German samples contain 2,603 and 738 individuals and 10,087 and 2,746 person-year observations, respectively.

Since there were some missing values in the observed gross wage, hours, and education measures we generated ten complete multiply imputed datasets which we use for all analyses. The imputation procedure fills missing values of certain variables in several steps. First, a value is drawn randomly out of the distribution of observed values. Then the random draw is replaced by predicted values which are obtained successively in twenty iteration steps. The process is repeated ten times with different random draws of the starting values and generates ten complete datasets without missing values. All ten are used in the analysis and inference procedures are adjusted following Rubin's rule (Rubin 1987 and Little and Rubin 1987).

The dependent variable measures log hourly wages in 2002 Euros. Wages are calculated based on current gross monthly incomes, which we divided by hours worked in the month of the interview. We apply current working hours because monthly income includes

\footnotetext{
${ }^{6}$ In future work we will investigate the determinants of the wage structure of female workers. Females, who make up the smaller part of the private sector work force are omitted here in order to generate a homogeneous sample and to avoid sample selection issues.
} 
overtime pay and thus likely varies with the actual number of hours worked. ${ }^{7}$ This allows for more precise measurement compared to studies based e.g. on the Panel Study of Income Dynamics (PSID) which only measures annual incomes or based on German unemployment insurance data which generate daily rather than hourly wages. Figure 1 characterizes the ageearnings profiles observed for the two groups. It immediately suggests that the regional difference is not only one of levels but also of life-cycle patterns. Figure 2a presents the life cycle wage structures for medium skill (with completed vocational education) and high skill groups (with completed tertiary education). It confirms the difference in wage levels across age groups for the two regions. To focus on the difference in the slopes of wage profiles Figure $2 \mathrm{~b}$ depicts life cycle wages relative to the wage level obtained by the youngest age group, again separately for both regions and skill groups. The difference in relative wage increases between the two regions appears to beginning with the age group of the 35-39 year olds. This might suggest that there is a cohort effect at work, which causes different valuations for labor force participation experience under the communist and the market oriented regimes. This hypothesis is tested below.

Our key explanatory variables are tenure and experience. Tenure measures the time spent with the current employer over all possible jobs at the monthly level. Experience similarly measures the sum of total full-time and part-time work experience. ${ }^{8}$ Both, tenure and experience are measured at the same time as the wage, i.e. at the time of the interview. To obtain the initial experience at the start of a job we calculated the difference between current experience and tenure: cases where the difference was smaller than minus two years

\footnotetext{
${ }^{7}$ Only if the respondent did not provide the number of current hours worked the contractual working hours were applied.

${ }^{8}$ Recent studies (e.g. Parent 2000) consider industry-specific experience. In our case it could be interesting to separately control for East or West German experience. Unfortunately, our data do not provide information at this level of detail.
} 
were dropped. ${ }^{9}$ Since the data does not inform on the date of job terminations, the exact value of initial work experience when taking on a new job cannot be determined. ${ }^{10}$ Since only those individuals can be considered in the Topel estimator which are observed in at least two subsequent periods, we censor observations in the first year of missing data (e.g. due to panel attrition).

Figure 3 illustrates the distribution of tenure and experience outcomes in East and West Germany: the share of East German employees with tenure values above 15 years is visibly smaller than in the West. This is exactly the pattern we would expect as a consequence of German unification and economic shifts starting in 1989. We find a somewhat lower share of workers with many years of work experience in the East, which is likely to be a consequence of intensive early retirement programs initiated at unification.

Our specification of the wage model considers cubic terms in both tenure and experience, a set of 6 indicators of highest educational attainment, immigrant status, federal state of residence ( 9 for West and 6 for East Germany), 12 industry indicators as well as calendar year fixed effects. The variables are described in Table 1 by subsample.

\section{4. $\quad$ Results}

\subsection{Main Results}

We start our analysis replicating prior studies and providing least squares results of the log wage equations, separately for East and West Germany in Table 2. For both regions the third order polynomials in tenure and experience were jointly highly statistically

9 This affected about 4.5 percent of our observations. In addition, in cases where the measured experience was slightly smaller than tenure, initial experience was replaced by the value of tenure and then updated based on subsequent observations.

10 We added half of the uncertain period as additional experience and considered the other half as unemployment. If e.g. a person started a new job in October and was employed on the old job in March the termination date of the old job could be at any point between March and October. We added half of this uncertain period (three of the six months from April to September) to the prior experience value, on average 2 months. This uncertainty affected about 5 percent of all person-year observations. 
significant mostly at the one percent level. We applied these estimates to predict the wage effects of ten years tenure and experience (see columns 1 and 4 in Table 3). A comparison of the predicted effects yields very similar correlations between seniority and wages in East and West Germany: staying with the same employer for ten years is associated with 14 percent higher wages based on the OLS coefficients in both regions. The predicted returns to experience are somewhat larger in West Germany. The standard errors are generated by block-bootstrap of the observations in the unbalanced panel for each of the multiply imputed datasets (e.g. Rubin 1987, Rubin and Little 1987). We tested the hypothesis that the OLS parameter estimates of tenure and experience differ significantly between East and West Germany. These tests yield similar returns to tenure but significantly different returns to experience in a fully interacted model. This is illustrated in Figure 4, where we plot the impact of experience on predicted wages in East and West Germany. ${ }^{11}$ The resulting patterns differ substantially. In addition, we tested whether the predicted effects of tenure and experience in Table 3 are identical in East and West Germany. The hypothesis is rejected at the 10 percent significance level for the highest experience values.

Since these results suffer from the correlation between covariates and error terms we applied the more advanced approaches by Altonji and Shakotko (1987) and Topel (1991) to estimate the returns to tenure and experience using the same specification as in Table 2 . The predicted impact of the first 5 and 10 years of tenure and experience using both estimators are described in the remaining columns in Table 3 separately for the two regions. Overall, the results confirm expectations. As in much of this literature we obtain for both regions vastly reduced returns to tenure when the AS estimator is applied, in fact they turn even negative for East Germany. The predictions are not significantly different from zero. ${ }^{12}$ The returns to

\footnotetext{
${ }^{11}$ We consider a person with five years tenure, born in Germany, observed in 2006, employed in the energy sector with intermediate education, and residing either in Saxony or North-Rhine Westphalia.

${ }^{12}$ In their analysis for Switzerland Luchsinger et al. (2003) similarly observed a drop from significant 7.5 percent wage increase with ten years of tenure based on OLS to an insignificant 1.7 percent when
} 
experience obtained with the AS estimator are very similar to the least squares results in both cases, again showing higher returns to experience in West Germany. The plot of the impact of experience on predicted wages in Figure 4 yields a somewhat dampened curvature compared to the least squares results.

Next, we apply the Topel estimator which identifies the causal returns to tenure and experience if job changes are exogenous (columns 3 and 6 in Table 3). ${ }^{13}$ The resulting returns to tenure lie between the OLS and AS results but are hardly significant. We find a value of 7 percent return to ten years of tenure for West and twice this rate, 13.8 percent for East Germany. The returns to experience for the West German sample are significantly different from zero throughout and much above the levels obtained for East Germany: while ten years of work experience in West Germany yield a return of 44 percent, they increase East German wages only by 22 percent. Thus, even 20 years after reunification the life cycle earnings patterns are still substantially flatter in East than West Germany.

\subsection{Robustness Tests}

We complemented the above analyses by two immediate tests. First, we repeated all analyses after adding six categorical firm size indicators to the specification. Even though the firm size effects were jointly significant in almost all estimations they did not affect the predicted returns to tenure and experience. Second, we evaluated whether the results for East Germany in Table 3 are sensitive to controlling for third order polynomials. Since the sample size is small this might have caused some overfitting. We redid the analysis for East Germany using only second order polynomials and obtained returns to experience that were even smaller than those presented in Table 3.

they applied the AS estimator. Dustmann and Pereira (2008) find a drop from a significant 12.8 percent to a small negative value for West German data from 1984-1999, as well.

${ }^{13}$ The results of the first and second step Topel estimation for the West German case are provided in Appendix Table 1. 
In a first robustness test we repeated our analyses separately for individuals of different skill groups. Dustmann and Meghir (2005) found for West Germany, that skilled workers benefited much more from general labor market experience than unskilled workers. So, if the average worker in East Germany was less skilled than his West German colleague this might have caused the observation of different returns to experience.

We estimated separate models for workers in three skill categories. The skill groups are defined following the literature: ${ }^{14}$ workers without a vocational education (e.g. without an apprenticeship) are considered as low skill workers. We observe 5 and 13 percent of our East and West German samples in that group. Medium skill workers are those who completed a vocational degree (more than 72 and 64 percent of the East and West German samples, respectively) and high skill workers are those who hold a tertiary education degree, which is observed for about 22 percent in both regions. The mere skill distribution in the two regional subsamples does not seem to support the skill based explanation of differences in life-cycle wage structures.

The predicted returns to experience and tenure for medium and high skill groups are presented in Table 4. In contrast to Dustmann and Pereira (2008) who added skill interaction terms to their specification we estimated separate equations for the different skill groups to flexibly account for potential differences in composition effects across skill groups. We do not present the results for low skill workers because they are based on very small samples which do not yield informative results. For the other skill groups the returns to tenure are somewhat mixed. Returns to tenure in the East exceed those in the West, in the West they are higher for medium skill workers, in the East they are higher for high skill workers. Even when we sort the sample by skill group we find significantly lower returns to experience in the East than in the West for all subgroups. In addition, the returns to experience are higher for those with high than with medium skills. Generally, the higher returns to experience in

\footnotetext{
${ }^{14}$ See e.g. Dustmann and Meghir (2005), Dustmann and Pereira (2008), or Fitzenberger (1999).
} 
West Germany appear to be driven by high skill workers, whose relative wage gains due to experience are about twice as high as those observed for medium skill workers.

As a further test of whether the results presented above are indicative of a different wage structure in the two German regions we repeated the analysis considering only workers born 1970 or later. These individuals' labor market history should not be affected by personal employment experience under the East German socialist regime. If we find subdued returns to experience even for them it suggests ongoing differences in the earnings structures rather than cohort effects. We applied the same estimation and prediction procedure as described above, only now omitting cubic tenure and experience terms from the specification to avoid overfitting. ${ }^{15}$ The results are presented in Table 5. Our main conclusions hold up when the younger sample is considered: under least squares the returns to tenure are similar across regions, and the returns to experience are significantly higher in the West. Under the AS estimator the returns to tenure diminish. The predictions based on the Topel procedure yield larger returns to tenure in the East and substantially larger returns to experience in the West. This suggests that the different returns to experience are not due to cohort effects but instead to systematic regional wage-structure differences.

\subsection{Aggregate Wage Trends}

One might argue that with respect to the development of individual earnings low returns to work experience can be complemented and balanced by high overall real wage increases over time. Thus if general wage trends have steeper slopes in East Germany than in the West the impact of lower returns to experience were ameliorated.

As our estimations control for the overall development in real wages we can inspect the evidence on this point. The year indicators in the least squares estimates in Table 2

\footnotetext{
${ }^{15}$ For this sample we observed mean values of tenure of 4.2 years in the East and 4.7 years in the
} West. Mean experience amounted to 7.6 years in the East and 8.3 years in the West. 
illustrate ceteris paribus real average wage increases between 2002 and 2006 of 6.4 percent in West and 7.8 percent in East Germany, which implies annual increases of about 1.6 and 1.9 percent. While eastern wages generally grow somewhat faster this cannot balance the lower returns to experience of about 20 percentage points in ten years (c.f. Tables 3 and 5).

When we compare the aggregate wage trends across skill groups, we find larger wage increases in the regressions for high skilled than for medium or low skilled workers. While this differs from Dustmann and Pereira's (2008) finding for the 1990s it agrees well with the overall widening of the income distribution in recent years (Dustmann et al. 2007).

Thus, overall secular wage growth is somewhat larger in East than in West Germany. Yet in the individual life cycle this effect is too small to make up for subdued returns to experience in East Germany.

\section{Conclusions}

The literature on the adjustment of wage structures in transition economies suffers from two major shortcomings: first, it concentrates almost exclusively on the returns to schooling and disregards the life-cycle perspective of wage structures. Second, it generally relies on least squares estimation which does not account for important biases in the estimation of wage determinants.

This paper contributes to that literature by studying the returns to tenure and experience based on more appropriate estimators. We analyze the wage structure of a transition economy and compare the East German life-cycle wage patterns with those in West Germany, a region with the same institutional framework but no heritage of a centrally planned economy. Previous studies found flat age-earnings profiles in East Germany immediately after unification in the early 1990s. Our data allow us to investigate the patterns between 2002 and 2006, almost two decades after the fall of the iron curtain. 
Our results confirm that not much has changed since the early 1990s. The wageexperience profile in East Germany is substantially flatter than in the West. To test whether this is driven by different skill compositions among East and West German workers we separately estimate the returns to human capital by skill level. However, returns to experience are much lower for East than West German workers across all skill groups. Alternatively, the low returns to experience might be due to a cohort effect and determined by those workers whose experience became obsolete at the economic transition and who may be more likely to be employed in positions that do not match their - at times outdated - qualifications. We estimate our models separately only for those younger birth cohorts who gathered their entire labor market experience after unification. However, even for these individuals we find significantly lower returns to experience in East than in West Germany.

This opens the intriguing research question of why the returns to human capital differ systematically and significantly between the two regions, even after controlling for composition effects related to education, industry, firm size, and region. In a recent contribution Fuchs-Schündeln and Izem (2008) emphasize that productivity differentials between East and West Germany are not due to worker characteristics but instead must be explained by differences in firm characteristics, regional public policy, or the cooperation between firms (see also Uhlig 2006 and 2008). This finding corroborates our conclusion that there are indeed systematic regional - rather than individual - differences between East and West Germany affecting the wage structure. In future research we plan to consider the following possible explanations: (i) the wage structure might be the result of selective emigration from East Germany, if only those with the least life-cycle productivity growth stayed (Hunt 2006). This possibility contradicts the conclusion of Fuchs-Schündeln and Izem (2008) yet in the face of continuing emigration from East Germany it deserves attention. (ii) Possibly, continued education activities are predominantly used in West Germany. In that case different life-cycle wage developments reflect systematically different additions to 
productivity over time, which might be complemented by different deferred compensation patterns in the two regions. (iii) Employees in the two regions might be differently affected by collective bargaining. We know that East German employers are less likely to be a member in employer associations (Kohaut and Schnabel 2003). This could explain the observed results if the union-contracts tend to prescribe age-based wage structures. (iv) Finally, independent of institutional differences in the collective bargaining frameworks, lifecycle wage structures might be affected by differences in the negotiating power of older workers in East and West Germany. One way to learn about any such differences could be to compare wage curves in East and West Germany by age group. Buscher (2003) finds unusually high wage elasticities in East Germany overall. It would be interesting to compare this evidence for different age groups and to test the hypothesis of monopsonistic labor markets for older employees in East Germany.

This research yields three conclusions. First, even today East German workers could on average gain substantially over the life-cycle by moving West. Second, there seems to be little benefit to using public funds to keep otherwise unemployed East German workers in subsidized employment, as the East German labor market does not seem to reward work experience. Third, studies which celebrate the arrival of market economies based on an analysis of returns to schooling alone might be jumping too short. Based on a comparison with the West German benchmark we find evidence for substantially subdued life-cycle wage structures in the transition economy of East Germany, even close to twenty years after unification and even for those workers who entered the labor force after unification. Therefore the transition process might be much more protracted than had been assumed so far and - to the extent that returns to tenure and experience reflect real productivity differentials the productivity gap between economic systems may have been larger than assumed so far. 


\section{References}

Altonji, Joseph G. and Robert A. Shakotko, 1987, Do Wages Rise with Job Seniority?, Review of Economic Studies 54, 437-459.

Andrén, Daniela, John S. Earle, and Dana Sapatoru, 2005, The wage effects of schooling under socialism and in transition: Evidence from Romania, 1950-2000, Journal of Comparative Economics 33(2), 300-323.

Bird, Edward J., Johannes Schwarze and Gert G. Wagner, 1994, Wage effects of the move toward free markets in East Germany, Industrial and Labor Relations Review 47(3), 390-400.

Boeri, Tito and Christopher J. Flinn, 1999, Returns to Mobility in the Transition to a Market Economy, Journal of Comparative Economics 27(1), 4-32.

Burda, Michael C., 2006, Factor Reallocation in Eastern Germany after Reunification, American Economic Review: Papers and Proceedings, 96(2), 368-374.

Burda, Michael C., 2008, What kind of shock was it? Regional integration and structural change in Germany after unification, forthcoming: Journal of Comparative Economics.

Burda, Michael C. and Jennifer Hunt, 2001, From Reunification to Economic Integration: Productivity and the Labor Market in Eastern Germany, Brookings Papers on Economic Activity 2, 1-92.

Burda, Michael C. and Christoph M. Schmidt, 1997, Getting behind the East-West Differential: Theory and Evidence, in: Pohl, Rüdiger and Hilmar Schneider (eds.), Wandeln oder Weichen - Herausforderungen der wirtschaftlichen Integration für Deutschland, IWH Halle, 170-201.

Buscher, Herbert S., 2003, Gibt es eine Lohnkurve in den neuen Bundesländern? Mitteilungen aus der Arbeitsmarkt- und Berufsforschung 36(4), 461-475.

Dustmann, Christian and Costas Meghir, 2005, Wages, Experience and Seniority, Review of Economic Studies 72(1), 77-108.

Dustmann, Christian, Johannes Ludsteck, and Uta Schönberg, 2007, Revisiting the German Wage Structure, IZA Discussion Paper No. 2685, Bonn.

Dustmann, Christian and Sonia C. Pereira, 2008, Wage Growth and Job Mobility in the United Kingdom and Germany, Industrial and Labor Relations Review 61(3), 374-393.

Fertig, Michael, Christoph M. Schmidt, and Hilmar Schneider, 2006, Active labor market policy in Germany - Is there a successful policy strategy?, Regional Science and Urban Economics 36(3), 399-433.

Finnie, Ross, 1993, Tenure, Experience, and Men's and Women's Wages: Panel Estimates from the National Longitudinal Survey of Youth, Cahier de recherché 9305, Quebec, Universite de Laval.

Fitzenberger, Bernd, 1999, Wages and Employment Across Skill Groups. An Analysis for West Germany, ZEW Economic Studies, Physica Verlag, Heidelberg.

Flanagan, Robert J., 1998, Were communists good human capitalists? The case of the Czech Republic, Labour Economics 5, 295-312.

Fleisher, Belton, Klara Sabirianova, and Xiaojun Wang, 2005, Returns to skills and the speed of reforms: Evidence from Central and Eastern Europe, China, and Russia, Journal of Comparative Economics 33(2), 351-370.

Franz, Wolfgang und Viktor Steiner, 2000, Wages in the East German Transition Process: Facts and Explanations, German Economic Review 1(3), 241-269.

Fuchs-Schündelen, Nicola und Rima Izem, 2008, Explaining the Low Labor Productivity in East Germany - A Spatial Analysis, mimeo, Harvard University. 
Gathmann, Christina, 2005, The Skill Loss of Older East Germans after Unification, Schmollers Jahrbuch 125(1), 7-16.

Görzig, Bernd, Martin Gornig, and Axel Werwatz, 2008, Firm Wage Differentiation in Eastern Germany: A Non-parametric Analysis of the Wage Spread, Economics of Transition 16(2), 273-292.

Gorodnichenko, Yuriy and Klara Sabirianova Peter, 2005, Returns to Schooling in Russia and Ukraine: A Semiparametric approach to cross-country comparative analysis, Journal of Comparative Economics 33(2), 324-350.

Hunt, Jennifer, 2001, Post-Unification Wage Growth in East Germany, Review of Economics and Statistics 83(1), 190-195.

Hunt, Jennifer, 2006, Staunching Emigration from East Germany: Age and the Determinants of Migration, Journal of the European Economic Association 4(5), 1014-1037.

Jones, Derek C. and Kosali Ilayperuma Simon, 2005, Wage determination under plan and early transition: Bulgarian evidence using matched employer-employee data, Journal of Comparative Economics 33(2), 227-243.

Jurajda, Stepan, and Heike Harmgart, 2007, When do female occupations pay more?, Journal of Comparative Economics 35(1), 170-187.

Kohaut, Susanne and Claus Schnabel, 2003, Tarifverträge-nein danke!? Einflussfaktoren der Tarifbindung west- und ostdeutscher Betriebe, Jahrbücher für Nationalökonomie und Statistik 223(3), 312-331.

Krueger, Alan B. and Jorn-Steffen Pischke, 1995, A Comparative Analysis of East and West German Labor Markets: Before and after Unification, in: Richard B. Freeman and Lawrence F. Katz (eds.), Differences and Changes in Wage Structures, Chicago: University of Chicago Press, 405-445.

Little, R.J.A. and Donald B. Rubin, 1987, Statistical Analysis with Missing Data, Wiley and Sons, New York.

Liu, Amy Y.C., 2006, Changing wage structure and education in Vietnam, 1992-1998. The roles of demand, Economics of Transition 14(4), 681-706.

Luchsinger, Cornelia, Rafael Lalive, and Jörg Wild, 2003, Do Wages Rise with Seniority? The Swiss Case, Swiss Journal of Economics and Statistics 139(2), 207-229.

Münich, Daniel, Jan Svejnar, and Katherine Terrell, 2005, Returns to Human Capital under the Communist Wage Grid and during the Transition to a Market Economy, Review of Economics and Statistics 87(1), 100-123.

Noorkoiv, Rivo, Peter F. Orazem, Allan Puur, and Milan Vodopivec, 1997, How Estonia's Economic Transition Affected Employment and Wages (1989-1995), Policy Research Working Paper 1837, World Bank, Washington D.C.

Parent, Daniel, 2000, Industry-Specific Capital and the Wage Profile: Evidence from the National Longitudinal Survey of Youth and the Panel Study of Income Dynamics, Journal of Labor Economics 18(2), 306-323.

Rubin, Donald B., 1987, Multiple Imputation for Nonresponse in Surveys, Wiley and Sons, New York.

Snower, Dennis J. and Christian Merkl, 2006, The Caring Hand that Cripples: The East German Labor Market after Reunification, American Economic Review 96(2), 375-382.

SOEP Group, 2001, The German Socio-Economic Panel (GSOEP) after more than 15 years Overview. In: Elke Holst, Dean R. Lillard, and Thomas A. DiPrete (eds.): Proceedings of the 2000 Fourth International Conference of German Socio-Economic Panel Study Users (GSOEP2000), Vierteljahrshefte zur Wirtschaftsforschung 70(1), 7-14. 
Spitz-Oener, Alexandra, 2007, Human Capital, Job Tasks and Technology in East Germany after Reunification, National Institute Economic Review 201, 97-106.

Steiner, Viktor and Lutz Bellmann, 1995, The East German Wage Structure in the Transition to a Market Economy, Labour: Review of Labour Economics and Industrial Relations 9(3), 539560.

Topel, Robert, 1991, Specific Capital, Mobility, and Wages: Wages Rise with Seniority, Journal of Political Economy 99(1), 145-176.

Uhlig, Harald, 2006, Regional Labor Markets, Network Externalities and Migration: The Case of German Reunification, American Economic Review 96(2), 383-387.

Uhlig, Harald, 2008, The slow decline of East Germany, forthcoming: Journal of Comparative Economics. 
Figure 1 Life Cycle Wage Structure in East and West Germany

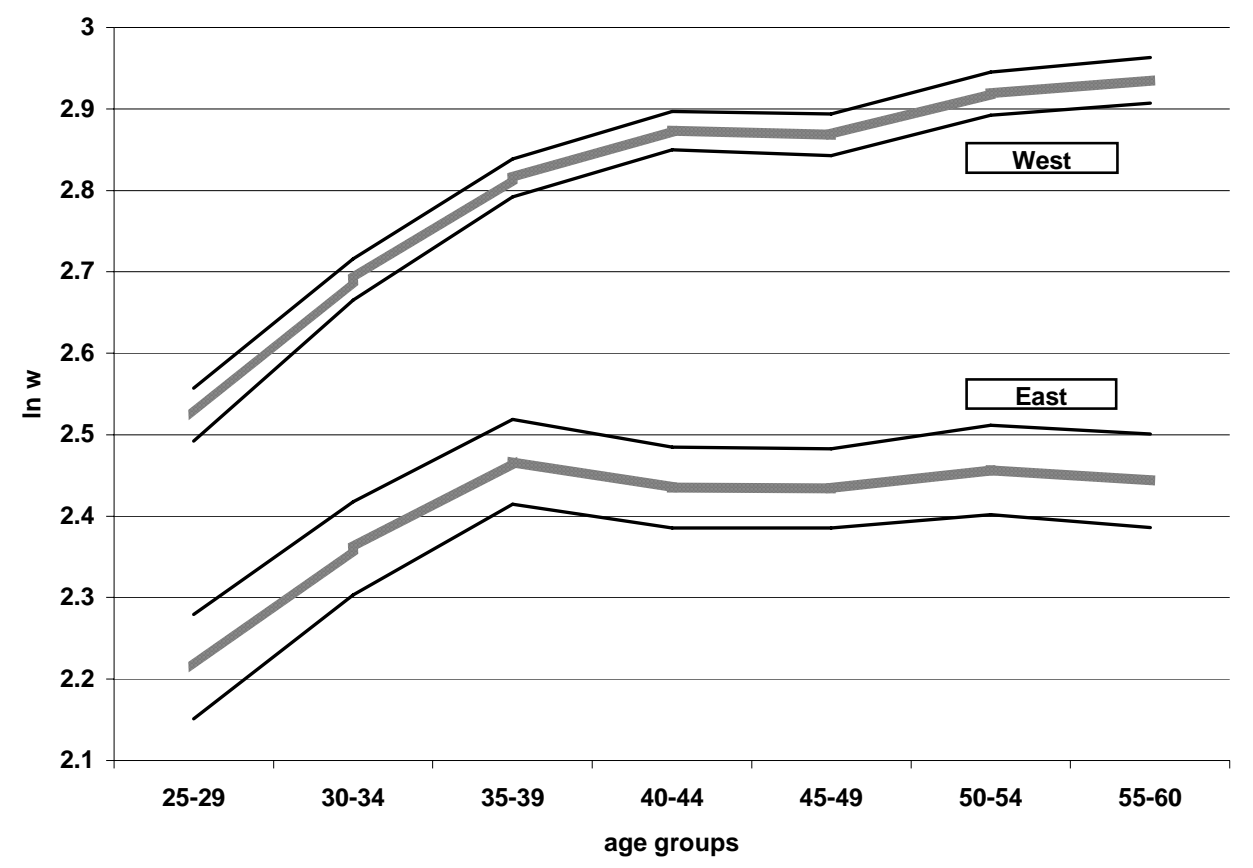

Note: Real hourly wages are deflated to 2002 prices. Estimates were obtained by regressing real log hourly wages on a set of indicator variables for age group and year. The dashed lines are pointwise 95 percent confidence intervals obtained from least squares standard errors adjusted for multiple imputation.

Source: Germany Socio-Economic Panel (2002-2006), own calculations. 
Figure 2 Life Cycle Wage Structure by Region and Skill Group: Log-Level and Groupwise Indexed to wages of age group 25-29

(a) Log Real Hourly Wages by Region and Skill Group

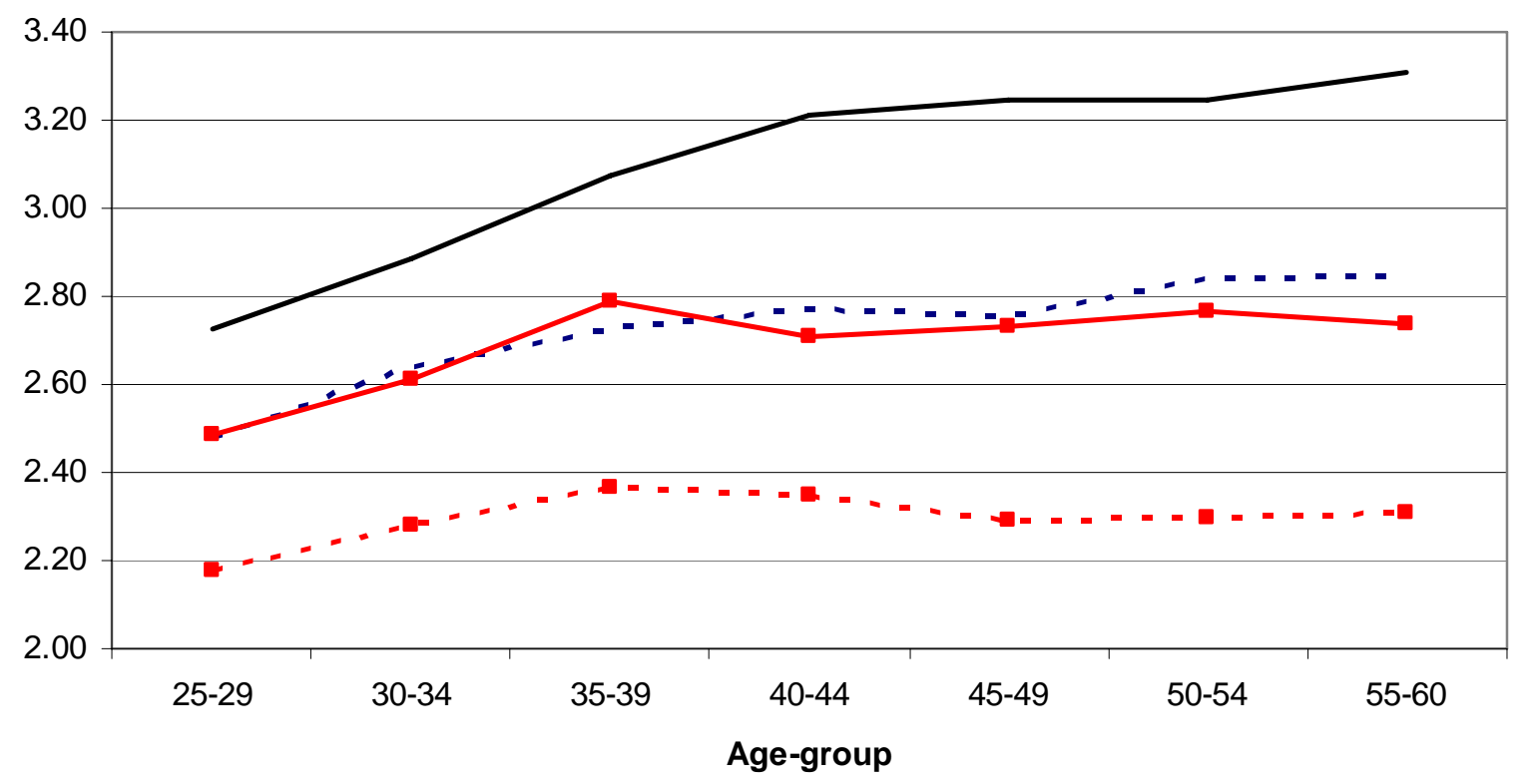

- - - - West-Skill —West-High Skill - - - - East-Skill $\longrightarrow$ East-High Skill

(b) Log Real Hourly Wages Indexed to Age-group 25-29

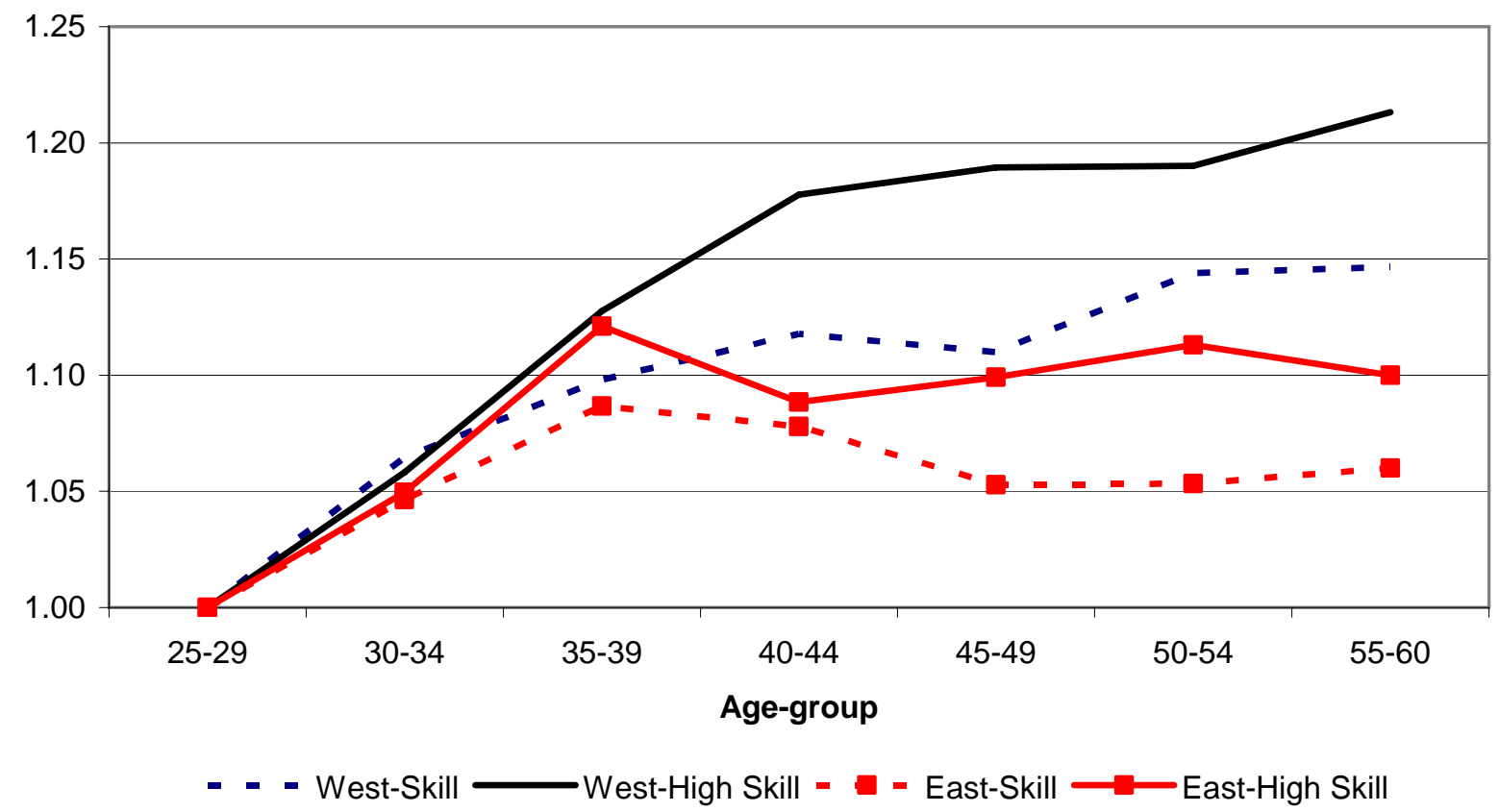

Note: Skill stands for workers with completed vocational training, high skill represents those with completed tertiary degree. The wage development of workers without vocational training is not presented because of small sample sizes.

Source: Germany Socio-Economic Panel (2002-2006), own calculations. 
Figure 3 Tenure and Experience in East and West Germany

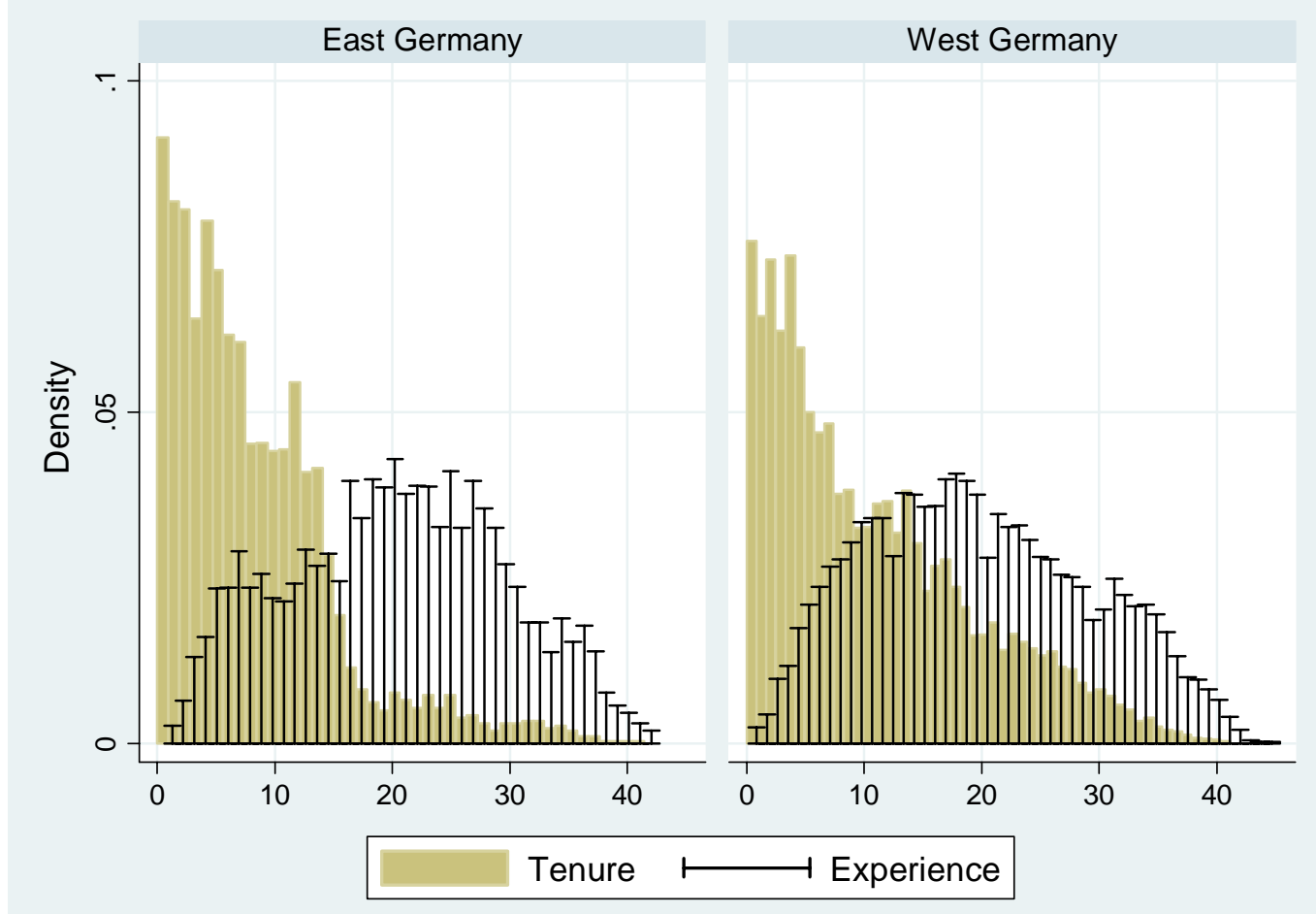

Source: Germany Socio-Economic Panel (2002-2006), own calculations. 
Figure 4 Estimated Polynomials in Experience in East and West based on Least Squares and Instrumental Variables Estimation (AS)

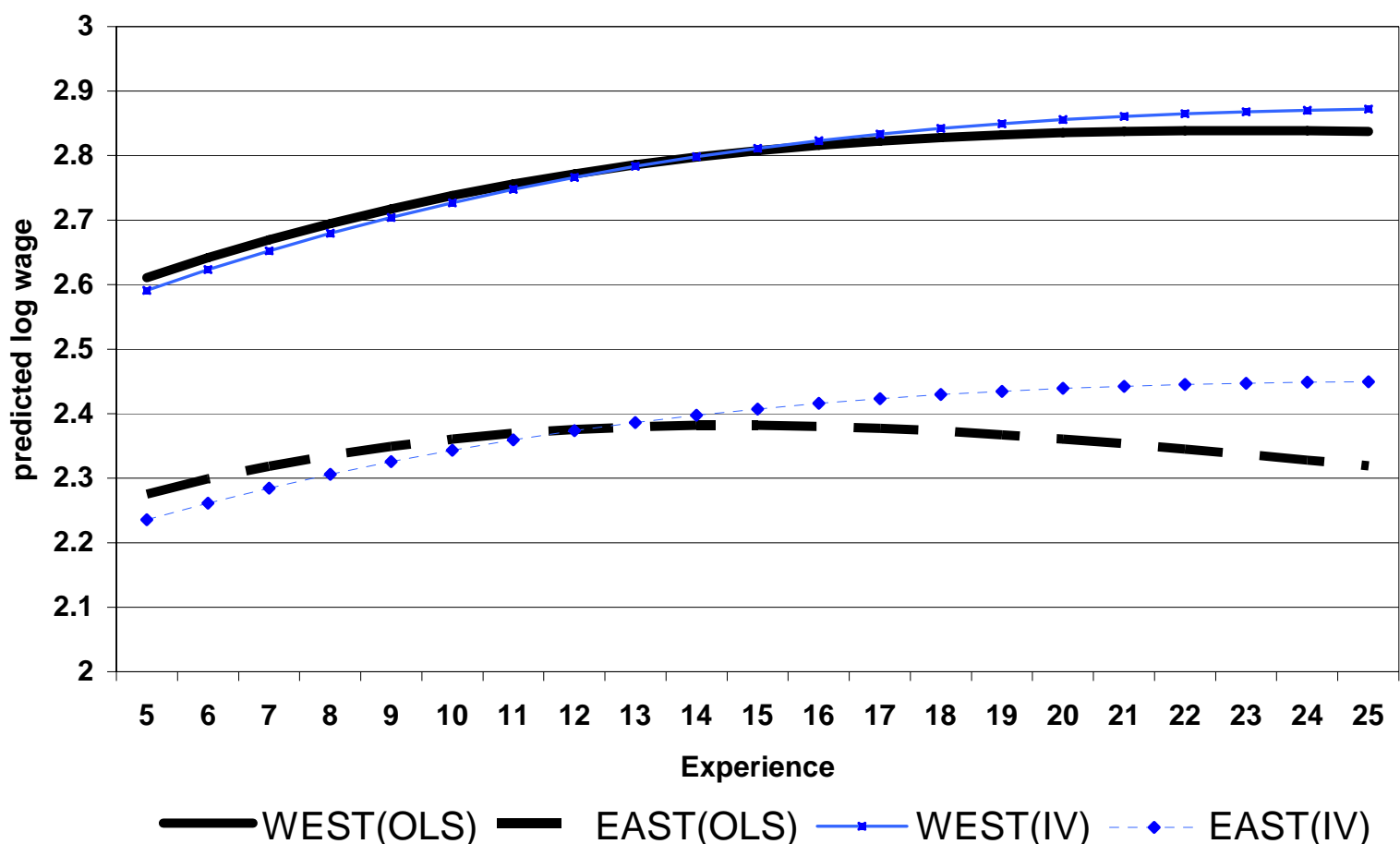

Note: The wages were predicted for individuals with five years tenure, born in Germany, observed in 2006, employed in the energy sector with intermediate education, and residing either in Saxony or NRW. The predictions are based on the OLS and AS estimates. 
Table 1 Descriptive Statistics

\begin{tabular}{|c|c|c|}
\hline & $\begin{array}{l}\text { West Germany } \\
\text { Mean (Std. Dev.) }\end{array}$ & $\begin{array}{c}\text { East Germany } \\
\text { Mean (Std. Dev.) }\end{array}$ \\
\hline \multicolumn{3}{|l|}{ Dependent Variable } \\
\hline log real hourly wage & $2.82(.0013)$ & $2.41(.0026)$ \\
\hline \multicolumn{3}{|l|}{ Explanatory Variables } \\
\hline Tenure & $10.79(.0275)$ & $8.26(.0423)$ \\
\hline Experience & $19.73(.0301)$ & $20.36(.0561)$ \\
\hline Education: Lower Secondary School & $.3934(.0015)$ & $.1400(.0021)$ \\
\hline Education: Intermediate Sec. School & $.2034(.0013)$ & $.5609(.0030)$ \\
\hline Education: Upper Secondary & $.0850(.0009)$ & $.0470(.0013)$ \\
\hline Education: University, Technical College & $.2224(.0013)$ & $.2345(.0026)$ \\
\hline Education: Other / Missing & $.0958(.0009)$ & $.0175(.0008)$ \\
\hline State: Schleswig-Holstein & $.0310(.0005)$ & - \\
\hline State: Hamburg & $.0170(.0004)$ & - \\
\hline State: Lower Saxony & $.1015(.0010)$ & - \\
\hline State: Bremen & $.0074(.0003)$ & - \\
\hline State: North Rhine-Westphalia & $.2779(.0014)$ & - \\
\hline State: Hesse & $.0919(.0009)$ & - \\
\hline State: Rhineland-Palatinate, Saarland & $.0803(.0009)$ & - \\
\hline State: Baden-Württemberg & $.1957(.0012)$ & - \\
\hline State: Bavaria & $.1974(.0013)$ & - \\
\hline State: Berlin & - & $.1211(.0020)$ \\
\hline State: Mecklenburg-Vorpommern & - & $.0786(.0016)$ \\
\hline State: Brandenburg & - & $.1375(.0021)$ \\
\hline State: Saxony-Anhalt & - & $.1772(.0023)$ \\
\hline State: Thuringia & - & $.1887(.0024)$ \\
\hline State: Saxony & - & $.2969(.0028)$ \\
\hline Born in Germany & $.8268(.0012)$ & $.9800(.0008)$ \\
\hline Industry: Not Applicable & $.0102(.0003)$ & $.0288(.0010)$ \\
\hline Industry: Agriculture & $.0438(.0006)$ & $.0438(.0012)$ \\
\hline Industry: Energy & $.2945(.0014)$ & $.2068(.0024)$ \\
\hline Industry: Mining & $.1524(.0011)$ & $.1156(.0019)$ \\
\hline Industry: Manufacturing & $1019(.0010)$ & $.1662(.0022)$ \\
\hline Industry: Construction & $.1120(.0010)$ & $.1344(.0021)$ \\
\hline Industry: Trade & $.0988(.0009)$ & $.0758(.0016)$ \\
\hline Industry: Transport & $.0872(.0009)$ & $.0971(.0018)$ \\
\hline Industry: Bank, Insurance & $.0207(.0004)$ & $.0387(.0012)$ \\
\hline Industry: Services & $.0455(.0007)$ & $.0488(.0013)$ \\
\hline Industry: Other & $.0025(.0002)$ & $.0022(.0003)$ \\
\hline Industry: Missing & $.0306(.0005)$ & $.0418(.0012)$ \\
\hline Number of person-year observations & 10,087 & 2,746 \\
\hline
\end{tabular}

Source: Germany Socio-Economic Panel (2002-2006), own calculations. 
Table 2 OLS Regression Results - Dependent Variable: log wages

\begin{tabular}{|c|c|c|}
\hline & $\begin{array}{c}\text { West } \\
\text { Germany }\end{array}$ & $\begin{array}{c}\text { East } \\
\text { Germany }\end{array}$ \\
\hline Tenure/10 & $\begin{array}{l}.1651^{* * *} \\
{[.0447]}\end{array}$ & $\begin{array}{l}.1349 \\
{[.0930]}\end{array}$ \\
\hline Tenure $^{2 / 100}$ & $\begin{array}{l}-.0229 \\
{[.0319]}\end{array}$ & $\begin{array}{l}.0140 \\
{[.0718]}\end{array}$ \\
\hline Tenure $^{3} / 1000$ & $\begin{array}{l}-.0008 \\
{[.0062]}\end{array}$ & $\begin{array}{l}-.0099 \\
{[.0142]}\end{array}$ \\
\hline Exp/10 & $\begin{array}{l}. \mathbf{4 8 4 2} \text { *** } \\
{[.0669]}\end{array}$ & $\begin{array}{l}. \mathbf{4 4 4 6 * *} \\
{[.1453]}\end{array}$ \\
\hline Experience $^{2} / 100$ & $\begin{array}{l}-.1781^{* \star *} \\
{[.0361]}\end{array}$ & $\begin{array}{l}-.2162^{\star * *} \\
{[.0767]}\end{array}$ \\
\hline Experience $^{3} / 1000$ & $\begin{array}{l}.0211^{\star * *} \\
{[.0057]}\end{array}$ & $\begin{array}{l}.0292^{\star *} \\
{[.0120]}\end{array}$ \\
\hline Educ: Intermediate & $\begin{array}{l}.1272^{\star * \star} \\
{[.0162]}\end{array}$ & $\begin{array}{l}.0143 \\
{[.0391]}\end{array}$ \\
\hline Educ: Upper secondary & $\begin{array}{l}.2837^{* * *} \\
{[.0236]}\end{array}$ & $\begin{array}{l}.2008^{\star * *} \\
{[.0750]}\end{array}$ \\
\hline Educ: Univ., techn. College & $\begin{array}{l}.5017^{* * *} \\
{[.0168]}\end{array}$ & $\begin{array}{l}.3952^{* * *} \\
{[.0462]}\end{array}$ \\
\hline Educ: Other / Missing & $\begin{array}{l}.0156 \\
{[.0211]}\end{array}$ & $\begin{array}{l}-.0787 \\
{[.1278]}\end{array}$ \\
\hline Born in Germany & $\begin{array}{l}.0926^{\star * \star} \\
{[.0175]}\end{array}$ & $\begin{array}{l}.2630^{* \star} \\
{[.1226]}\end{array}$ \\
\hline 2003 & $\begin{array}{l}.0420 * * * \\
{[.0068]}\end{array}$ & $\begin{array}{l}.0213^{*} \\
{[.0121]}\end{array}$ \\
\hline 2004 & $\begin{array}{l}.0469 * * * \\
{[.0076]}\end{array}$ & $\begin{array}{l}.0552^{\star * *} \\
{[.0145]}\end{array}$ \\
\hline 2005 & $\begin{array}{l}.0501^{\star * *} \\
{[.0087]}\end{array}$ & $\begin{array}{l}.0631^{\star * *} \\
{[.0160]}\end{array}$ \\
\hline 2006 & $\begin{array}{l}.0642^{* * *} \\
{[.0089]}\end{array}$ & $\begin{array}{l}.0776 * * * \\
{[.0184]}\end{array}$ \\
\hline Constant & 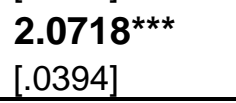 & $\begin{array}{l}1.6786^{* * *} \\
{[.1470]}\end{array}$ \\
\hline State of Residence & yes & yes \\
\hline Industry & yes & yes \\
\hline Observations & 10,087 & 2,746 \\
\hline R-squared & 0.38 & 0.33 \\
\hline
\end{tabular}

Notes:

(a) $* * *, * *$ and $*$ indicate statistical significance at the 1, 5 and 10 percent level.

(b) The coefficients of the indicators for state of residence, industry, and calendar year are not presented to save space. Standard errors are calculated based on Rubin's Rule for multiply imputed data using Stata's micombine command.

Source: Germany Socio-Economic Panel (2002-2006), own calculations. 
Table 3 Predicted Returns to Tenure and Experience in East and West Germany with Alternative Estimators - Full Sample

\begin{tabular}{|c|c|c|c|c|c|c|}
\hline & \multicolumn{3}{|c|}{ West Germany } & \multicolumn{3}{|c|}{ East Germany } \\
\hline & (1) & (2) & (3) & (4) & (5) & (6) \\
\hline & OLS & AS & Topel & OLS & AS & Topel \\
\hline 5 vs 0 yrs Tenure & $\begin{array}{l}.0767 \\
(.0150)\end{array}$ & $\begin{array}{l}-.0079 \\
(.0178)\end{array}$ & $\begin{array}{l}.0452 \\
(.0243)\end{array}$ & $\begin{array}{l}.0697 \\
(.0312)\end{array}$ & $\begin{array}{l}-.0298 \\
(.0282)\end{array}$ & $\begin{array}{c}.0497 \\
(.0493)\end{array}$ \\
\hline 10 vs 0 yrs Tenure & $\begin{array}{l}.1413 \\
(.0204)\end{array}$ & $\begin{array}{l}.0055 \\
(.0307)\end{array}$ & $\begin{array}{l}.0704 \\
(.0493)\end{array}$ & $\begin{array}{l}.1390 \\
(.0419)\end{array}$ & $\begin{array}{l}-.0639 \\
(.0513)\end{array}$ & $\begin{array}{r}.1378 \\
(.0933)\end{array}$ \\
\hline 5 vs 0 yrs Experience & $\begin{array}{l}.2002 \\
(.0237)\end{array}$ & $\begin{array}{l}.1993 \\
(.0281)\end{array}$ & $\begin{array}{l}.2249 \\
(.0433)\end{array}$ & $\begin{array}{l}.1719 \\
(.0551)\end{array}$ & $\begin{array}{l}.1631 \\
(.0725)\end{array}$ & $\begin{array}{c}.1424 \\
(.0830)\end{array}$ \\
\hline 10 vs 0 yrs Experience & $\begin{array}{l}.3273 \\
(.0353)\end{array}$ & $\begin{array}{l}.3353 \\
(.0450)\end{array}$ & $\begin{array}{l}.4372 \text { *** } \\
(.0868)\end{array}$ & $\begin{array}{l}.2576 \\
(.0822)\end{array}$ & $\begin{array}{l}.2709 \\
(.3003)\end{array}$ & $\begin{array}{r}.2175 \\
(.1669)\end{array}$ \\
\hline 20 vs 0 yrs Experience & $\begin{array}{l}.4223 \\
(.0381)\end{array}$ & $\begin{array}{l}.4639 \\
(.0615)\end{array}$ & $\begin{array}{l}.8301 \\
(.1804)\end{array}$ & $\begin{array}{l}.2576 \\
(.0868)\end{array}$ & $\begin{array}{r}.3666 \\
(.2338)\end{array}$ & $\begin{array}{r}.2871 \\
(.3478)\end{array}$ \\
\hline
\end{tabular}

Notes:

(a) ***,** and * indicate statistical significance at the 1, 5 and 10 percent level.

(b) Shaded cells indicate a significant difference in the predicted wage effects between East and West Germany at least at the 10 percent level. Assuming no correlation between the predicted wage effects, the z-test statistic divides the difference in predicted wage values (DW) by the square root of the sum of their variances:

$$
Z=\left(D W_{\text {West }}-D_{\text {east }}\right) /\left[\operatorname{var}\left(D_{W_{\text {West }}}\right)+\operatorname{var}\left(D_{W_{\text {West }}}\right)\right]^{0.5}
$$

(c) The standard errors were obtained via block-bootstrap using 100 replications based on ten multiply imputed data sets.

(d) The underlying regression models are specified as in Table 2.

(e) The OLS and AS returns were predicted based on regressions with 10,087 person-year observations for West and 2,746 person-year observations for the East German sample. The first step of the Topel-estimator used 2,509 and 698 observations, the second step is based on 616 and 214 observations in East and West Germany, respectively.

(f) The last row with predictions for 20 versus 0 years of experience certainly contains out of sample predictions.

Source: Germany Socio-Economic Panel (2002-2006), own calculations. 
Table 4 Returns to Tenure and Experience in East and West Germany according to Alternative Estimators - By Skill Group

(a) Medium Skilled (Person-Year Observations West: 6508, East: 1953)

\begin{tabular}{|c|c|c|c|c|c|c|}
\hline & \multicolumn{3}{|c|}{ West Germany } & \multicolumn{3}{|c|}{ East Germany } \\
\hline & (1) & (2) & (3) & (4) & (5) & (6) \\
\hline & OLS & AS & Topel & OLS & AS & Topel \\
\hline \multirow[t]{2}{*}{5 vs 0 yrs Tenure } & $.0829 * \star \star$ & -.0125 & .0424 * & $.0873 * \star *$ & -.0213 & $.1125 * \star \star$ \\
\hline & $(.0105)$ & $(.0236)$ & $(.0243)$ & $(.0252)$ & $(.0341)$ & $(.0393)$ \\
\hline \multirow[t]{2}{*}{10 vs 0 yrs Tenure } & $.1501 * * *$ & -.0143 & .0936 ** & $.1585 * * *$ & -.0526 & $.1959 * \star *$ \\
\hline & $(.0180)$ & $(.0452)$ & $(.0422)$ & $(.0433)$ & $(.0640)$ & $(.0652)$ \\
\hline \multirow{2}{*}{5 vs 0 yrs Experience } & $.0917 \star \star \star *$ & .1399 ** & $.1514 * \star \star$ & .0360 & .1533 & .0440 \\
\hline & $(.0148)$ & $(.0707)$ & $(.0305)$ & $(.0262)$ & $(.1321)$ & $(.0473)$ \\
\hline \multirow[t]{2}{*}{10 vs 0 yrs Experience } & .1673 *** & $.2650 *$ & .2926 *** & .0608 & .2814 & .0983 \\
\hline & $(.0260)$ & $(.1402)$ & $(.0611)$ & $(.0459)$ & $(.2628)$ & $(.0946)$ \\
\hline \multirow[t]{2}{*}{20 vs 0 yrs Experience } & .2698 *** & .4710 & $.5443 * * *$ & .0768 & .4620 & .2371 \\
\hline & $(.0391)$ & $(.2779)$ & $(.1270)$ & $(.0666)$ & $(.5224)$ & (.1952) \\
\hline
\end{tabular}

(b) Highly Skilled (Person-Year Observations West: 2244, East: 643)

\begin{tabular}{|c|c|c|c|c|c|c|}
\hline 5 vs 0 yrs Tenure & $\begin{array}{l}.0258 \\
(.0253)\end{array}$ & $\begin{array}{l}-.0255 \\
(.0351)\end{array}$ & $\begin{array}{r}.0130 \\
(.0353)\end{array}$ & $\begin{array}{l}.1097 \\
(.0472)\end{array}$ & $\begin{array}{l}-.0865 * \\
(.0486)\end{array}$ & $\begin{array}{r}.1472 \\
(.0937)\end{array}$ \\
\hline 10 vs 0 yrs Tenure & $\begin{array}{l}.0623 \\
(.0416)\end{array}$ & $\begin{array}{l}-.0166 \\
(.0639)\end{array}$ & $\begin{array}{r}.0334 \\
(.0626)\end{array}$ & $\begin{array}{l}.1919 \\
(.0737)\end{array}$ & $\begin{array}{l}-.1875 \\
(.0934)\end{array}$ & $\begin{array}{l}.2795 \\
(.1363)\end{array}$ \\
\hline 5 vs 0 yrs Experience & $\begin{array}{l}.2298 \text { *** } \\
(.0322)\end{array}$ & $\begin{array}{l}.2321 \\
(.0607)\end{array}$ & $\begin{array}{l}.2974 \\
(.0484)\end{array}$ & $\begin{array}{c}.0978 \text { * } \\
(.0522)\end{array}$ & $\begin{array}{l}.0743 \\
(.2748)\end{array}$ & $\begin{array}{l}.1784 \text { ** } \\
(.0890)\end{array}$ \\
\hline 10 vs 0 yrs Experience & $\begin{array}{l}.4013 \\
(.0553)\end{array}$ & $\begin{array}{l}.4058 \\
(.1140)\end{array}$ & $\begin{array}{l}.5648 \\
(.0962)\end{array}$ & $\begin{array}{l}.1627 \text { * } \\
(.0899)\end{array}$ & $\begin{array}{r}.1414 \\
(.5486)\end{array}$ & $\begin{array}{l}.3331 \\
(.1744)\end{array}$ \\
\hline 20 vs 0 yrs Experience & $\begin{array}{l}.5696 \\
(.0755)\end{array}$ & $\begin{array}{l}.5779 \\
(.2038)\end{array}$ & $\begin{array}{l}1.0091 \text { *** } \\
(.2021)\end{array}$ & $\begin{array}{r}.1939 \\
(.1239)\end{array}$ & $\begin{array}{r}.2544 \\
(1.0973)\end{array}$ & $\begin{array}{r}.5710 \\
(.3579)\end{array}$ \\
\hline
\end{tabular}

Notes:

(a) See Notes below Table 3.

(b) The underlying regression models follow the specification in Table 2, where we use second instead of third order polynomials in tenure and experience in order to avoid overfitting.

Source: Germany Socio-Economic Panel (2002-2006), own calculations. 
Table 5 Predicted Returns to Tenure and Experience in East and West Germany with Alternative Estimators - Sample of Individuals born after 1969

\begin{tabular}{|c|c|c|c|c|c|c|}
\hline & \multicolumn{3}{|c|}{ West Germany } & \multicolumn{3}{|c|}{ East Germany } \\
\hline & (1) & (2) & (3) & (4) & (5) & (6) \\
\hline & OLS & AS & Topel & OLS & AS & Topel \\
\hline 5 vs 0 yrs Tenure & $\begin{array}{l}.0963 \\
(.0284)\end{array}$ & $\begin{array}{r}.0279 \\
(.0401)\end{array}$ & $\begin{array}{l}.0827 \text { * } \\
(.0430)\end{array}$ & $\begin{array}{l}.1034 \text { * } \\
(.0560)\end{array}$ & $\begin{array}{l}-.1116 \\
(.0763)\end{array}$ & $\begin{array}{l}.0598 \\
(.0670)\end{array}$ \\
\hline 10 vs 0 yrs Tenure & $\begin{array}{l}.1561 \\
(.0348)\end{array}$ & $\begin{array}{l}.0611 \\
(.0753)\end{array}$ & $\begin{array}{l}.1216 \\
(.0840)\end{array}$ & $\begin{array}{l}.1344 \\
(.0667)\end{array}$ ** & $\begin{array}{l}-.1589 \\
(.1378)\end{array}$ & $\begin{array}{l}.1520 \\
(.1702)\end{array}$ \\
\hline 5 vs 0 yrs Experience & $\begin{array}{l}.2142{ }^{* * *} \\
(.0408)\end{array}$ & $\begin{array}{l}.2251 \\
(.0549)\end{array}$ & $\begin{array}{l}.1891 \\
(.0672)\end{array}$ & $\begin{array}{l}-.0381 \\
(.1039)\end{array}$ & $\begin{array}{l}.1474 \text { * } \\
(.0843)\end{array}$ & $\begin{array}{l}.0212 \\
(.1390)\end{array}$ \\
\hline 10 vs 0 yrs Experience & $\begin{array}{l}.3366 \\
(.0559)\end{array}$ & $\begin{array}{l}.3665 \\
(.0955)\end{array}$ & $\begin{array}{l}.3229 \\
(.1376)\end{array}$ & $\begin{array}{l}.0315 \\
(.1422)\end{array}$ & $\begin{array}{l}.2800 \\
(.1307)\end{array}$ & $\begin{array}{r}.1220 \\
(.2888)\end{array}$ \\
\hline 20 vs 0 yrs Experience & $\begin{array}{l}.30588^{* * *} \\
(.0693)\end{array}$ & $\begin{array}{l}.3984 \\
(.1916)\end{array}$ & $\begin{array}{l}.4247 \\
(.3282)\end{array}$ & $\begin{array}{l}.4941 \\
(.1412)\end{array}$ & $\begin{array}{l}.5012 \\
(.2277)\end{array}$ & $\begin{array}{r}.5621 \\
(.7282)\end{array}$ \\
\hline
\end{tabular}

Notes:

(a) See Notes below Table 3.

(b) The underlying regression models follow the specification in Table 2, where we use second instead of third order polynomials in tenure and experience in order to avoid overfitting.

(c) The OLS and AS returns were predicted based on regressions with 2069 person-year observations for West and 534 person-year observations for the East German sample. The first step of the Topel estimator used 1752 and 448 observations, the second step is based on 2069 and 534 observations in East and West Germany, respectively.

Source: Germany Socio-Economic Panel (2002-2006), own calculations. 


\section{Appendix}

Table A1: Estimation Results of the Topel estimator for West Germany

\begin{tabular}{|c|c|c|c|}
\hline \multicolumn{2}{|c|}{ Topel estimation (1st step) } & \multicolumn{2}{|c|}{ Topel estimation (2nd step) } \\
\hline$\Delta$ tenure/10 & $\begin{array}{l}.5775 * \star * \\
.1080\end{array}$ & initial exper./10 & $\begin{array}{l}.4634 \text { *** } \\
.0486\end{array}$ \\
\hline$\Delta$ tenure $^{2} / 100$ & $\begin{array}{l}.0088 \\
.0479\end{array}$ & initial exper. ${ }^{2} / 100$ & $\begin{array}{r}-.0283 \\
.0404\end{array}$ \\
\hline$\Delta$ tenure $^{3} / 1000$ & $\begin{array}{l}.0020 \\
.0101\end{array}$ & initial exper. ${ }^{3} / 1000$ & $\begin{array}{r}.0021 \\
.0089\end{array}$ \\
\hline$\Delta$ exper. ${ }^{2} / 100$ & $\begin{array}{r}-.0877 \\
.0587\end{array}$ & educ_intermediate & $\begin{array}{l}.1843 \text { *** } \\
.0183\end{array}$ \\
\hline$\Delta$ exper. ${ }^{3} / 1000$ & $\begin{array}{r}.0071 \\
.0091\end{array}$ & educ_upper sec. & $\begin{array}{l}.3848 \text { *** } \\
.0263\end{array}$ \\
\hline$\Delta$ educ_Sec.School & $\begin{array}{r}-.0911 \\
.1049\end{array}$ & educ_university & 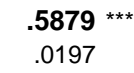 \\
\hline$\Delta$ educ_intermed. & $\begin{array}{c}-.1958 \text { * } \\
.1068\end{array}$ & educ_other/missings & $\begin{array}{r}-.0011 \\
.0279\end{array}$ \\
\hline$\Delta$ educ_upper sec. & $\begin{array}{r}-.1854 \\
.4702\end{array}$ & state_Schleswig-Hols. & $\begin{array}{c}-.0848 \text { ** } \\
.0386\end{array}$ \\
\hline$\Delta$ educ_university & $\begin{array}{r}-.0755 \\
.1064\end{array}$ & state_Hamburg & $\begin{array}{r}-.0618 \\
.0598\end{array}$ \\
\hline$\Delta$ educ_other & $\begin{array}{r}-.0974 \\
.0940\end{array}$ & state_Lower Saxony & $\begin{array}{r}-.0249 \\
.0265\end{array}$ \\
\hline$\Delta$ state_Schleswig-H. & $\begin{array}{r}.1251 \\
.0803\end{array}$ & state_Bremen & $\begin{array}{r}-.0366 \\
.0794\end{array}$ \\
\hline$\Delta$ state_Hamburg & $\begin{array}{r}-.0294 \\
.0523\end{array}$ & state_N-Rhein-Westfa. & $\begin{array}{r}-.0303 \\
.0206\end{array}$ \\
\hline$\Delta$ state_Lower Saxony & $\begin{array}{r}-.0816 \\
.0889\end{array}$ & state_Hessen & $\begin{array}{r}-.0110 \\
.0267\end{array}$ \\
\hline$\Delta$ state_Bremen & $\begin{array}{l}.1827 \text { *** } \\
.0049\end{array}$ & state_R-Pfalz,Saarl. & $\begin{array}{r}-.0199 \\
.0259\end{array}$ \\
\hline$\Delta$ state_N-Rhein-Westfa & $\begin{array}{r}.1720 \\
.1982\end{array}$ & state_Baden-Wuertt. & $\begin{array}{l}.0655 \text { *** } \\
.0216\end{array}$ \\
\hline$\Delta$ state_Hessen & $\begin{array}{r}-.0175 \\
.0534\end{array}$ & Born in Germany & $\begin{array}{l}.0753 \text { *** } \\
.0214\end{array}$ \\
\hline$\Delta$ state_R-Pfalz,Saarl. & $\begin{array}{r}-.1984 \\
.2089\end{array}$ & ind_Not Applicable & $\begin{array}{c}-.3294 \text { *** } \\
.0869\end{array}$ \\
\hline$\Delta$ state_Baden-Wuertt. & $\begin{array}{c}-.0556 * \star \star \\
.0176\end{array}$ & ind_Agriculture & $\begin{array}{c}-.1036 \text { *** } \\
.0357\end{array}$ \\
\hline$\Delta$ state_Bavaria & $\begin{array}{r}-.0836 \\
.0569\end{array}$ & ind_Mining & $\begin{array}{r}.0167 \\
.0199\end{array}$ \\
\hline$\Delta$ ind_Not Applicable & $\begin{array}{c}-.2604 \text { * } \\
.1542\end{array}$ & ind_Manufacturing & $\begin{array}{c}-.0674 \text { *** } \\
.0211\end{array}$ \\
\hline$\Delta$ ind_Agriculture & $\begin{array}{r}-.0552 \\
.0510\end{array}$ & ind_Construction & $\begin{array}{c}-.1140 \text { *** } \\
.0219\end{array}$ \\
\hline$\Delta$ ind_Energy & $\begin{array}{r}-.0327 \\
.0343\end{array}$ & ind_Trade & $\begin{array}{r}-.0313 \\
.0256\end{array}$ \\
\hline Dind_Mining & $\begin{array}{r}.0162 \\
.0264\end{array}$ & ind_Transport & $\begin{array}{r}.0334 \\
.0274\end{array}$ \\
\hline$\Delta$ ind_Manufacturing & $\begin{array}{c}-.0755 * \\
.0453\end{array}$ & ind_Bank,Insurance & $\begin{array}{r}.0013 \\
.0427\end{array}$ \\
\hline Dind_Construction & $\begin{array}{r}.0065 \\
.0402\end{array}$ & ind_Services & $\begin{array}{c}-.0573 \text { ** } \\
.0276\end{array}$ \\
\hline$\Delta$ ind_Trade & $\begin{array}{c}-.0773 \text { * } \\
.0415\end{array}$ & ind_Other & $\begin{array}{r}-.0629 \\
.0938\end{array}$ \\
\hline$\Delta$ ind_Transport & $\begin{array}{l}.0287 \\
.0443\end{array}$ & ind_Missing & $\begin{array}{c}-.0504 \text { * } \\
.0300\end{array}$ \\
\hline Sind_Bank,Ins. & $\begin{array}{r}-.0399 \\
.0324\end{array}$ & y2003 & $\begin{array}{l}.0319 \text { *** } \\
.0068\end{array}$ \\
\hline$\Delta$ ind_Services & $\begin{array}{r}-.0114 \\
.0499\end{array}$ & y2004 & $\begin{array}{l}.0339 \\
.0078\end{array}$ \\
\hline Dind_Other & $\begin{array}{r}.0712 \\
.0930\end{array}$ & y2005 & $\begin{array}{l}.0325 \\
.0092\end{array}$ \\
\hline$\Delta$ ind_Missing & $\begin{array}{r}-.0372 \\
.0644\end{array}$ & $\begin{array}{l}\text { y2006 } \\
\text { Constant }\end{array}$ & $\begin{array}{c}.0315 \\
.0092 \\
1.8676 \\
.0304\end{array}$ \\
\hline
\end{tabular}

The results are based on 10 multiply imputed datasets for West Germany. The first step estimation uses 9300 and the second step 10087 observations. 